Journal homepage: www.aesacademy.org

\title{
Performance of Agribusiness Microfinance Institutions (MFIA) by using approach of Context, Input, Process, and Product (CIPP) in district of Gunungkidul, Yogyakarta, Indonesia
}

\author{
Riris Nadia Syafrilia Gurning ${ }^{1^{*}}$ (D) , Jangkung Handoyo Mulyo ${ }^{2}$ and Masyhuri ${ }^{2}$ \\ ${ }^{1}$ Master of Agribusiness Management, Gadjah Mada University, Flora Street, Bulaksumur, Yogyakarta-55281, INDONESIA \\ ${ }^{2}$ Departement of Agricultural Socio-Economic, Gadjah Mada University, Flora Street, Bulaksumur, Yogyakarta-55281, INDONESIA \\ *Corresponding author's E-mail: risnagur@gmail.com
}

\section{ARTICLE HISTORY}

Received: 26 April 2019

Revised received: 05 May 2019

Accepted: 22 May 2019

\section{Keywords}

Agribusiness

CIPP

Institution

Microfinance

MFIA

Performance

\begin{abstract}
This investigation was aimed to analyze the performance of MFIA Rural Agribusiness Development Program in District of Gunungkidul. Program of Agribusiness Rural Enterprise Development aimed as stimulus that could developed into an MFIA for sustainable financing for farmers. The Agribusiness Microfinance Institution (MFIA) is the only financial institution established specifically to provide agricultural capital facilities in the countryside. This research was conducted at 65 of MFIA in District of Gunungkidul based on MFIA that had conducted the Annual Members Meetings (AMM) on January-March, 2018. Primary data collection was conducted through direct interviews using questionnaires with the manager of MFIA. Secondary data was obtained from the report of AMM 2017. The method used in this study was CIPP model (Context, Input, Process, Product). Based on the four performance indicators in CIPP models, the results shown that the performance of MFIA in District of Gunungkidul in 2017 was included in the good criteria.
\end{abstract}

(C)2019 Agriculture and Environmental Science Academy

Citation of this article: Gurning, R.N.S., Mulyo, J.H.M. and Masyhuri (2019). Performance of Agribusiness Microfinance Institutions (MFIA) by using approach of Context, Input, Process, and Product (CIPP) in district of Gunungkidul, Yogyakarta Indonesia. Archives of Agriculture and Environmental Science, 4(2): 190-197, https://dx.doi.org/10.26832/24566632.2019.0402010

\section{INTRODUCTION}

Indonesia is agricultural country, that means, agriculture has an important role to courage the national economy. This is indicated by the majority of Indonesia's population who working in agriculture and earning income from the agricultural sector. According to Statistics (2017), there were 27.771 million of Indonesia's population that included into poor people. There are about 17.097 out of $\mathbf{2 7 . 7 7 1}$ million poor people live in rural areas with the main livelihood in agricultural sector. Poverty in Indonesia is a phenomenon that is closely related to socioeconomic conditions in rural areas, generally and in agricultural sector, particularly. The study of (Setijowati, 2012) in analyzing the efficiency of MFIA's performance in province of Special Region of Yogyakarta, the poverty was most found in agricultural sector and concentrated in the area of Districts of Gunungkidul and Kulonprogo. Poverty in Special Region of Yogyakarta is still dominant among farmers, this needs more attention from the government.

(Saragih, 2015) states that farmers in rural areas are generally small-scale businesses but in large numbers. Small farmers are often unable to capture economies of scale in the fields of production, distribution, and services. This is the economic reason for the importance of a farmer's economic organization. The policy of developing 1 (one) farmer-based institution of the Combined Farmers Group (Gapoktan) in 1 (one) village is an effort of the Ministry of Agriculture to build a strong, independent farmer organization as the basis for economic growth which is expected to improve the economic performance of rural farmers.

The program of poverty reduction is the part of Long-term Development Plan and global agreement implementation to achieve millennium goals. The Ministry of Agriculture began in 2008 to implement the Program of Rural Agribusiness 
Enterprise Development (RAED), that is rural society empowerment program that aimed to develop agribusiness through the provision of capital in the form of Direct Assistance Program for Society (DAP-RAED) in the amount of IDR. 100 million per farmer group. Distribution of funds to farmers through the Agribusiness Microfinance Institution (MFIA) that formed and run by Farmer group (Ministry of Agriculture, 2014). The strengthening of venture capital funds of RAED, structurally rolled by Farmer group to the farmer groups member as the loans, thus in the 2nd year Farmer group is able to develop The Unit of Saving and Loan Business. Farmer group member who is recipient of Independent Direct Assistance-RAED expected to be able to maintain revolving funds until the growth phase of Agribusiness Microfinance Institutions (MFIA) in the 3rd year (Utami, 2015).

This effort is conducted by the government to solve the major problems of farmers in running the business system, such as: (1) the difficulty of the community in accessing capital; (2) the weakness of community capital, especially those belonging to the criteria of poor or small farmers. The development of MFIA in rural area is based on: (1) ease of access; (2) fast process; (3) simple procedure; (4) follow the local social culture and close to the business location; (5) manager of MFIA knows the character of farmers (customers); and (6) the existence of funds/assets handled by the group (Ministry of Agriculture, 2010). Research conducted by (Kurniati, 2016) shows the results of the t-statistic test on per capita income per month before and after the RAED program shows tangible results. It can be seen that the $p$ value is less than alpha 0.05 , meaning that there is a significant difference between income before the RAED program is implemented and after the RAED program is implemented in Indragiri Hulu Regency. In the research of (Nugroho et al., 2018) in the Special Province of Yogyakarta said that RAED is not only beneficial for farmers, but also has many problems including irregularities in RAED fund distribution, RAED funds that are not according to plan, bad credit and low human resource capacity.

Research on measuring the performance of MFIA has been carried out a lot, one of the studies conducted by (Saleh et al., 2013) in Bantul Regency, efforts to improve the performance of MFIA need to be done with internal and external approaches. The internal approach is related to improving the human resource management of reliable MFIA, and externally on growing customer awareness and optimizing the role of the government. Special efforts are needed in developing MFIA, considering there are many and varied types of other microfinance institutions that have been established especially in rural areas so that in order to maintain stability and existence, MFIA is required to continue to strive to carry out its functions as microfinance institution that providing facility to small farmers. This study aimed to measure the performance of MFIA in District of Gunungkidul by using the Context, Input, Process and Product (CIPP) method.

\section{MATERIALS AND METHODS}

\section{Studies sites}

The research was conducted in the Agribusiness Microfinance
Institute (MFIA) in District of Gunungkidul, Special Region of Yogyakata. Location was determinated purposively, deliberately with the consideration that MFIA in District of Gunungkidul had been formed since the beginning of the establishment of RAED program. In Province of Yogyakarta, District of Gunungkidul had the highest number of MFIA, they were 144 MFIA. The sampling technique in this study was conducted by using purposive sampling method with criteria of MFIA that had conducted the Annual Member Meeting (AMM) in 2017, that conducted from January to March 2018. According to these criteria, the samples that met the requirements were $65 \mathrm{MFIA}$. The type of data used in this study was primary data that obtained through structured interviews with manager of MFIA with the help of questionnaires. While secondary data obtained from the report of AMM 2017 that obtained from the manager of MFIA and information on the description of implementation, asset development and profile of MFIA in District of Gunungkidul which were obtained from related agency, Agriculture and Food Service of District of Gunungkidul and Penyelia Mitra Tani (PMT).

\section{CIPP method to measure the performance of MFIA}

Performance was the work ability and the results or achievements in implementing a program (Nawawi, 2017). The performance assessment of government program could also be conducted on performance evaluation system. Evaluation was a process for making systemic assessment regarding to policy, program, project or activity based on information and analytical results compared to the relevance, effectiveness, and success for the purposes of stakeholders (Suryahadi, 2017). Measurement performance by evaluation system on MFIA in order to provide information about institutional performance of MFIA and as consideration to determine the next steps for the continuation of MFIA. Conceptually, the evaluation model used in this study to measure the performance of MFIA was CIPP model that presented in Figure 1.

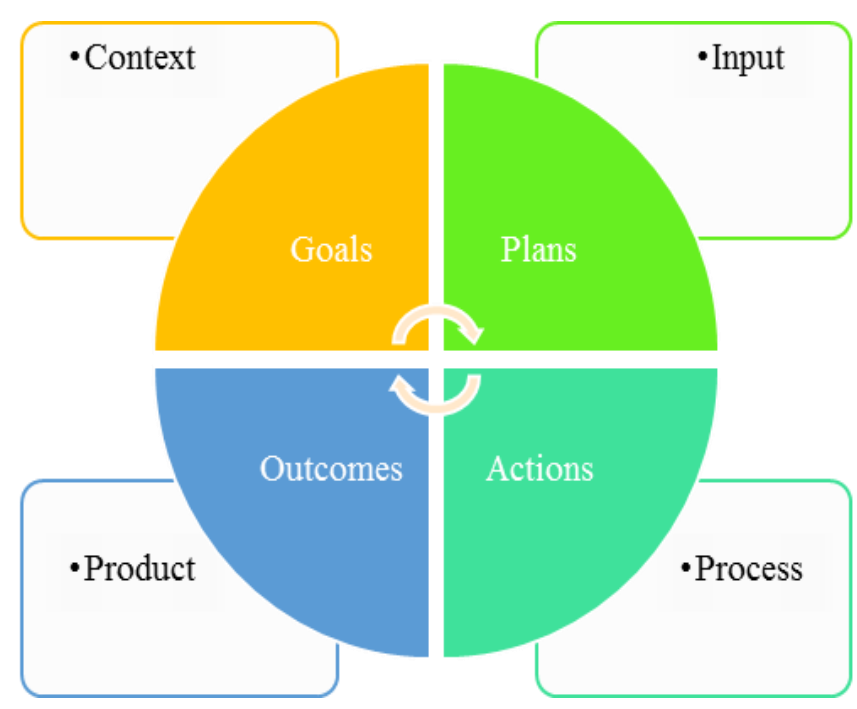

Figure 1. Component analysis of CIPP (Source: Stufflebeam, 2003). 
CIPP stood for Context, Input, Process and Product. CIPP was the first evaluation analysis introduced by Stufflebeam in 1971. CIPP was comprehensive instrument for evaluating on the level of personal, project, product, organizational and policy systems. Although, initially CIPP was used in education area, but later CIPP had been heavily modified for use in various disciplines (Stufflebeam, 2003). The purpose of CIPP was to look all of strategies and evaluation components and to seek the answers of the questions, whether the evaluation design that functioned properly? Which points were problematic and how could it be resolved? Was there a more efficient way to do? Collecting data? Stufflebeam suggested the evaluator to follow these steps, as a logical structure, to be used in types of evaluation: evaluation focus, gathering information, organizing information, information analysis, information reporting and administration evaluation (Hakan and Seval, 2011). Context indicator was an indicator of need. The purpose of context indicators to determine the relevant context, identify opportunities to address the problem and diagnose problems. Input indicator identified the procedural design to achieve predetermined objectives included assessing the strategy and the resources required and used to reach program. Process indicators were the indicators used to monitor the implementation of program. The process indicators in principle be used to provide feedback and documenting programs that required the implementation of policy. Product indicator was an indicator that identified the outcome of program. The purpose of indicators were to measure the product, translate and assess the success of the program.

The performance measurement using CIPP model assessed based on the criteria of each indicators, the context indicator consisted of four criteria, the input indicator consisted of six criteria, the process indicator consisted of ten criteria and product indicator consisted of seven criteria. The implementation performance indicators of MFIA in this study could be seen in Table 1 below. The answer of each respondent scored by scoring on an assessment of the performance of MFIA with scoring criteria of (1) Score 3 was given if the answer "a", (2) Score 2 was given if the answer " $b$ ", and Score 1 was given if the answer "c ". The answers of manager of MFIA in the form of questionnaires were calculated by total score per question, then the researcher could determine the performance criteria of manager of MFIA according to the table of criteria score that shown in table 2 to see whether the MFIA of District of Gunungkidul was in very bad, good or very good criteria.

The choice of answers from each question consisted of 3 answer choices, thus, to get maximum score from the number of questions should be multiplied by the number of answer choices. The next step was determine the quality of each criteria with maximum score of 100 with the difference value of each criteria was 25 . Then determined the equivalent value obtained from 100 divided by the minimum value of each criteria. To fill the value range of each criteria by dividing the maximum score value for each CIPP model with calculated equivalent value. These results become the minimum value of each criteria that were poor, good and very good.

After obtaining the scores of each indicator in the CIPP model, then matching the scores into table 2, thus, the criteria were known respectively. Based on table 2 , it could be seen that MFIA included into criteria of poor, good or very good.

Table 1. Indicator of performance measurement of MFIA.

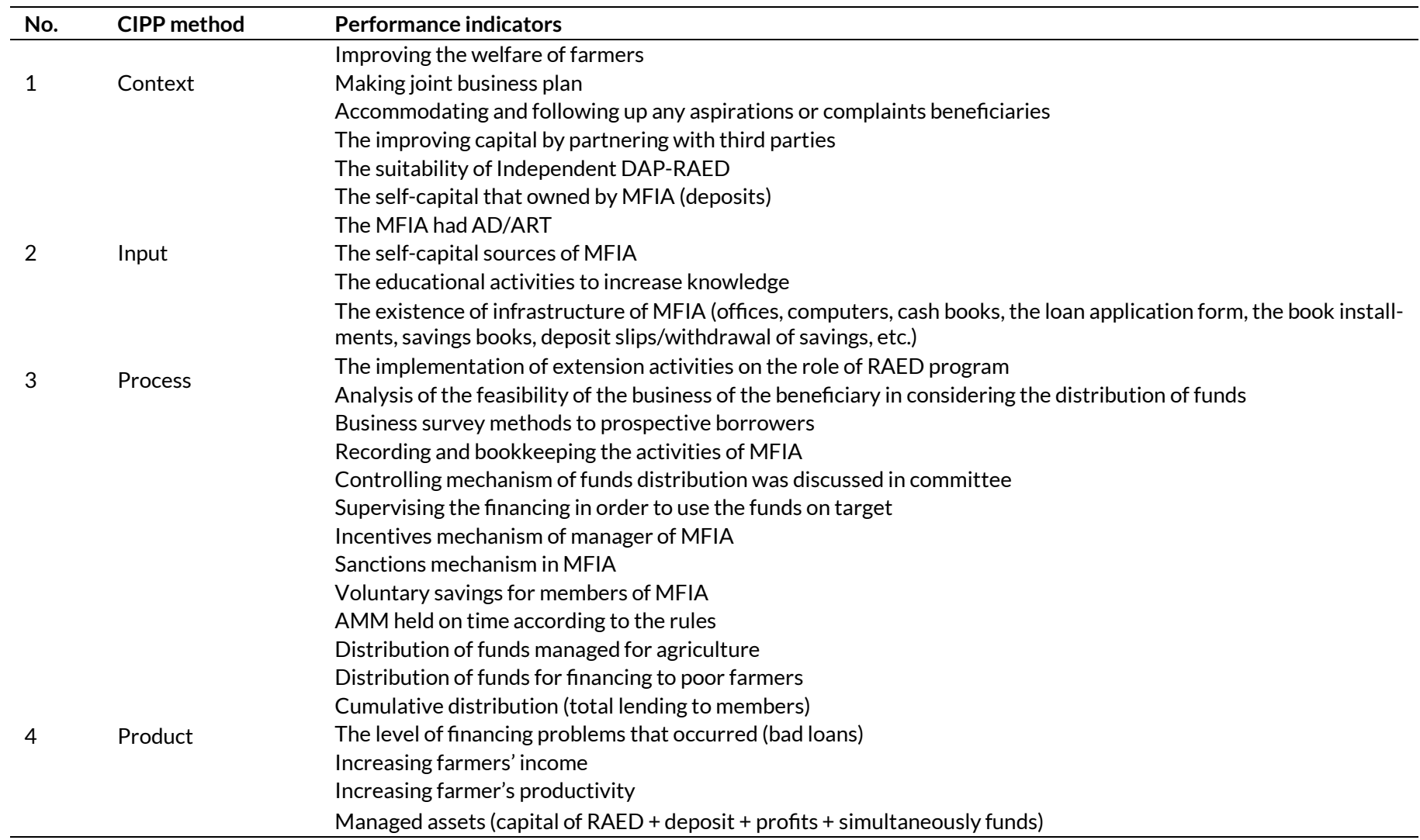


Table 2. Assessment score of criteria on each performance indicators.

\begin{tabular}{lcccc}
\hline \multirow{2}{*}{ Model CIPP } & \multirow{2}{*}{ Maximum score } & \multicolumn{3}{c}{ Score criteria } \\
\cline { 3 - 5 } & & Poor & Good & Very good \\
\hline Context & 12 & $3.00-5.99$ & $6.00-8.99$ & $9.00-12.00$ \\
Input & 18 & $4.50-8.99$ & $9.00-13.49$ & $13.50-18.00$ \\
Process & 30 & $7.50-14.99$ & $15.00-22.49$ & $22.50-30.00$ \\
Product & 21 & $5.25-10.49$ & $10.50-15.75$ & $15.75-21.00$ \\
Total of performance & 81 & $20.25-40.49$ & $40.50-60.74$ & $60.75-81.00$ \\
Quality & 100 & $25-49.99$ & $50-74.99$ & $75-100$ \\
Equivalent & & 4.00 & 2.00 & 1.33 \\
\hline
\end{tabular}

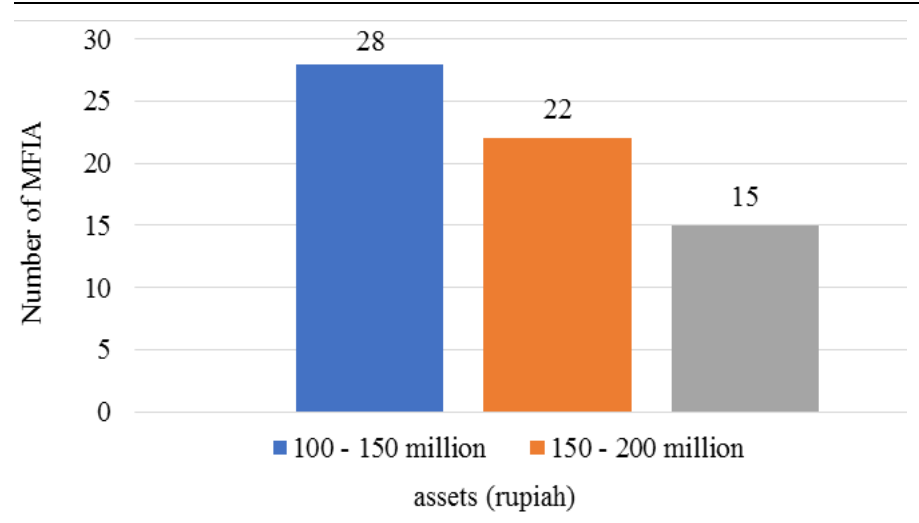

Figure 2. Total MFIA's assets of Gunungkidul, Indonesia.

\section{RESULTS AND DISCUSSION}

\section{The performance of MFIA}

The Program of Rural Agribusiness Development (RAED) in Gunungkidul had been running since 2008 until now 2018 and there were 143 villages out of 144 villages that received funding of Direct Assistance Program for Society (DAP) RAED. This meant that almost every village in District of Gunungkidul had RAED program. RAED program required the Farmer group institutional in every village as the recipient of DAP RAED that coming from the State Budget of Ministry of Agriculture. Furthermore, Farmer group directed to foster the formation of MFIA as one business unit that specialized in serving the financing Farmer group capital for micro-scale farmers. The difference in human resources and management in managing MFIA caused various of implementing patterns at MFIA. The loan method determined by each MFIA was different, as many as 38 MFIA (58.4\%) applied the loan method with the group method or it was known in the society as "joint responsibility", while 14 MFIA set loan method individually (21.5\%) and the rest serve loans with mixed methods, that was group and individual (20.1\%).

According to Figure 2 shown that from the initial capital of each MFIA the recipient of RAED was IDR 100 million, from the beginning of MFIA's development until now the assets owned by MFIA continued to grow, but these developments differed from each MFIA. There were 15 MFIA (23\%) that had succeeded in developing their assets up to more than IDR 200 million. This shown that around $23 \%$ of MFIA had successfully developed and were able to manage finances well. Good performance and management that could develop assets owned. While as many as 22 MFIA (34\%) classified as quite good because they were able to develop assets

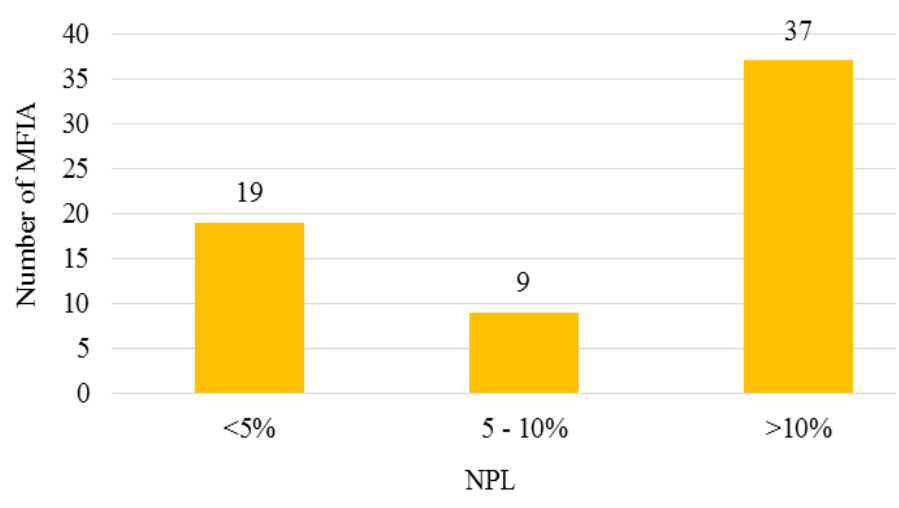

Figure 3. The NPL Level of MFIA in district of Gunungkidul, Indonesia.

owned with a value of IDR 150-200 million. But as many as 28 MFIA (43\%) had not been able to manage funds from the government, they only reached IDR 100 million-150 million, thus, the improvement of management was needed to get a solution on how the business was conducted to be able to increase the accumulated assets owned. According to Nugroho et al. (2018) the slow development of capital in District of Gunungkidul was caused by Farmer group institutions that needed to be strengthened as well as business activities that had not operated well.

According to Figure 3 shown that problematic financing level of MFIA in District of Gunungkidul dominantly was in the level of > $10 \%$ with total of 37 MFIA (57\%). Whereas MFIA which was at problematic financing level $<5 \%$ was 19 MFIA (29.2\%). This shown that determinant factor that also determined a MFIA as good MFIA was the customer. No matter how good management was shown by MFIA without being supported by a shared awareness to make progress and develop from the customer's side, the performance of MFIA would not be good.

\section{Validity and reliability}

Validity testing against the manager of MFIA used samples of 65 respondents who were interviewed using 27 questions that divided by each indicator on the CIPP model. The results of validity test shown that all questions were valid because they had the value of $r$ count was greater than $r$ table (0.244) which meant that each item was valid and suitable for research and as test instrument in research. The result of reliability test indicated that Cronbach alpha value of each variable was greater than the comparative alpha of 0.60 , which meant that each question that would be used in this study was reliable and appropriate for further research in analyzing the performance of MFIA. 
Table 3. Results of performance measurement in context indicators of MFIA in District of Gunungkidul, Indonesia.

\begin{tabular}{lll}
\hline Context criteria & Score & Achievement (\%) \\
\hline Improving the welfare of farmers & 2.46 & $82 \%$ \\
Preparation of a joint business plan & 2.20 & $73 \%$ \\
Accommodating and following up all aspirations and complaints of beneficiaries & 1.89 & $63 \%$ \\
The improving capital by partnering with third parties & 1.32 & $44 \%$ \\
Total & 7.87 & $65.6 \%$ \\
Interval & $(6.00-8.99)$ \\
\hline
\end{tabular}

Source: Analysis of Primary Data, 2018.

Table 4. The results of performance measurement in input indicators of MFIA in district of Gunungkidul, Indonesia.

\begin{tabular}{lll}
\hline Input criteria & Score & Achievement (\%) \\
\hline The suitability of Independent DAP-RAED & 2.41 & $80.3 \%$ \\
The self-capital that owned by MFIA (deposits) & 2.21 & $73.6 \%$ \\
The MFIA had AD/ART & 2.75 & $91.6 \%$ \\
The self-capital sources of MFIA & 1.49 & $49.6 \%$ \\
The educational activities to increase knowledge & 2.15 & $71.6 \%$ \\
The existence of infrastructure of MFIA (offices, computers, cash books, the loan application & 2.21 & $73.6 \%$ \\
form, the book installments, savings books, deposit slips/withdrawal of savings, etc.) & 13.24 \\
Total & 9.00 to 13.49 \\
Interval & $73.3 \%$ \\
\hline
\end{tabular}

Source: Analysis of Primary Data, 2018.

\section{Performance measurement of MFIA}

Performance assessment was systematic description of the strengths and weaknesses associated with a person or group of people. To evaluate the performance of MFIA which were recipients of DAP-RAED in District of Gunungkidul, the CIPP model was used (context, input, process, product). The performance assessment of MFIA could be seen in the Table 3.

According to the results of performance assessment of MFIA in context indicator could be concluded that the performance of MFIA in context indicator included into good criteria because it was included in the internal value of 6.00-8.99 with the total percentage of achievement was $65.6 \%$. One of the supporting factors of the context indicator was an effort to improve the welfare of farmers. The results of the study shown that $82 \%$ of MFIA had made improvements to the welfare of farmers as evidenced by the distribution of RAED program funds to had an impact on the welfare of farmers, especially micro-scale farmers. Another supporting factor in the context indicator was the making of a joint business plan that had score of 2.20 with percentage of achievement of $73 \%$. Based on these results, shown that almost every MFIA had made and carried out joint business plan with members. Furthermore, the supporting factors accommodated and followed up on the aspirations and complaints from customers. MFIA was at the percentage level of achievement of $63 \%$. This meant, there was $63 \%$ of the efforts that MFIA had made in addressing customer problems and following up on customer aspirations. Another supporting factor was the improving capital by partnering with third parties with percentage level of $44 \%$. This value was included in the lowest percentage level in context indicator because in reality there were not many MFIA that had cooperated with third parties in improving capital because it was valued by the amount of capital owned by MFIA that had fulfilled the loan request from the borrower.
Based on Table 4 above shown that the performance of MFIA in input indicators regarded to CIPP model was included in criteria of good. This was supported by the percentage achievement achieved by the input indicator of $73.3 \%$. The supporting factor in input indicator was the suitability of DAP-RAED funds, $80.3 \%$ of MFIA felt that the grant provided by the government was IDR 100 million per Farmer group in accordance with the needs of Farmer group members as MFIA borrowers. Self-capital owned by MFIA was obtained from principal savings, mandatory savings and voluntary savings, the acquisition of the three savings funds obtained from own members had reached $73.6 \%$. This meant that MFIA was able to collect the funds from members. The more self-capital, the greater the level of trust of members to MFIA. Almost all MFIA up to $91.6 \%$ who had had Articles of Association and Bylaws (AD/ART) as the guiding principle in running the MFIA. The next supporting factor in input indicators was the existence of educational activities to increase knowledge with an achievement percentage of $71.6 \%$. There was training to provide knowledge to the manager of MFIA, if it was important to be held routinely to provide input and provide understanding to Farmer group especially manager of MFIA, how to manage and make financial reporting that was understandable and used transparency system. Apart from training, the performance of MFIA performance was also assessed by the existence of infrastructure facilities owned by MFIA. The percentage of achievement was $73.6 \%$. Generally, MFIA in District of Gunungkidul did not have their own office in providing services to customers but service time was carried out in a village hall or in one of the Farmer group members' houses, but generally all MFIA had cash books, loan slips, and complete installments so that it could be concluded that MFIA infrastructure was available but limited.

According to Table 5 presented about the performance of MFIA in process indicator of CIPP model included criteria of good. 
This was indicated by the score obtained was 21.80 which was in the interval of good criteria, that was 15.00-22.49. The process indicator consisted of 10 criteria with total percentage of process indicator achievement reaching up to 72.6\%. Supporting factors in process indicators that had the highest percentage were implementation of Annual Member Meetings (AMM) with an achievement percentage of $88 \%$. Regarded to total samples of 65 respondents taken from this study, the implementation time of the AMM varied according to the policy of MFIA itself, but from the results above it was known that MFIA implemented the AMM on time in accordance with recommendations from the government in January. This was considered by MFIA to be disciplined with regulations. The supporting factor for process indicator which had a high percentage of achievement was the criteria for recording and bookkeeping with an achievement percentage of $84 \%$. According to these results, MFIA was considered to complete on recording and bookkeeping, meaning that all activities that conducted between manager of MFIA and customers had records such as those listed in the book, cash book and loan slip. While the supporting indicators of process indicators that had the lowest percentage of achievement were survey methods for prospective borrowers with the percentage of achievement was $53.3 \%$. The loan method applied by almost all of MFIA in District of Gunungkidul was by group method or as "joint responsibility". Borrowing funds at MFIA was conducted by each farmer group leader. So that the farmer group leader coordinated with the manager to assess the characteristics of each member so that the manager did not conduct a survey before giving a loan. One of the advantages of MFIA was that the manager had understood the characteristics of the members of Farmer group, thus, the manager known the track record of the members of each group. One of the inhibiting factors in process indicator which had low percentage achievement value was voluntary savings with percentage achievement of $57.6 \%$. Voluntary savings were savings of Farmer group's members whose numbers depend on the ability of the members themselves so they had a non-mandatory savings. As many as $57.6 \%$ of MFIA that had voluntary deposits, the rest MFIA obtained self-help funds from principal savings and compulsory savings collected from members every month and had been determined at the meeting of Farmer group.

According to Table 6, the results of MFIA performance measurements on product indicators in CIPP model included in very good criteria with an achievement percentage of $76.9 \%$. One of inhibiting factors of product indicators was the level of problematic financing (NPL) because it had the lowest achievement percentage of $56.6 \%$. It could not be denied that the problem of bad credit was the biggest problem in running financial institutions. Smooth money circulation was one of the important factors in assessing the performance of an MFIA. The results of the study shown that the cause of fund turnover were stalled due to the lack of customer awareness in providing loan installments in accordance with the agreement between customers and the manager of MFIA, thus, this affected the number of MFIA borrowers because they had to wait for funds to be available at MFIA to make further loans. The solution that conducted by the manager to avoid credit congestion was by conducting approach to the customer or borrower and find solutions to the problems that faced by the customer.

Table 5. The Results of performance measurement in process indicators of MFIA in district of Gunungkidul, Indonesia.

\begin{tabular}{lll}
\hline Process criteria & Score & Achievement (\%) \\
\hline Implementation of extension activities to challenge the role of RAED program & 2,49 & $83 \%$ \\
The feasibility analysis in utilizing the consideration of fund distribution & 1.64 & $54.6 \%$ \\
Business survey methods to prospective borrowers & 1.60 & $53.3 \%$ \\
Recording and bookkeeping activities MFIA & 2.52 & $84 \%$ \\
Controlling mechanism the distribution of funds was discussed in committee & 2.46 & $82 \%$ \\
Supervising the financing in order to use the funds on target & 2.38 & $79.3 \%$ \\
Incentives mechanism to manager of MFIA & 2.21 & $73.6 \%$ \\
Sanction mechanism in MFIA & 2.09 & $69.6 \%$ \\
Voluntary savings for MFIA's members & 1.73 & $57,6 \%$ \\
AMM held on time according to the rules & 2.64 & $88 \%$ \\
Total & 21.80 & $72.6 \%$ \\
Interval & $15.00-22.49$ \\
\hline
\end{tabular}

Source: Analysis of Primary Data, 2018.

Table 6. Results of performance measurement in product indicators of MFIA in district of Gunungkidul, Indonesia.

\begin{tabular}{lll}
\hline Product criteria & Score & Achievement (\%) \\
\hline Distribution of funds managed for agriculture & 2.61 & $87 \%$ \\
Distribution of funds for financing to poor farmers & 2.41 & $80.3 \%$ \\
Cumulative distribution (total lending to members) & 2,27 & $75.6 \%$ \\
The level of financing problems that occurred (bad loans) & 1.70 & $56.6 \%$ \\
Increasing farmers' income & 2,67 & $89 \%$ \\
Increasing farmer's productivity & 2,69 & $89.6 \%$ \\
Managed assets (capital of RAED + deposit + profits + simultaneously funds) & 1.78 & $59.3 \%$ \\
Total & 16.16 & $76.9 \%$ \\
Interval & $15.75-21.00$ \\
\hline
\end{tabular}

Source: Analysis of Primary Data, 2018. 
Table 7. Total performance measurement of MFIA in district of Gunungkidul, Indonesia.

\begin{tabular}{lll}
\hline Indicators of CIPP & Score & Criteria \\
\hline Context & 7,87 & Good \\
Input & 13.24 & Good \\
Process & 21.80 & Good \\
Product & 16.16 & Very good \\
Total & 59.07 & \\
Interval & $40.50-60.74$ & Good \\
\hline
\end{tabular}

Source: Analysis of Primary Data, 2018.

One of the supporting factors of the measurement of MFIA performance on product indicators was the increase in productivity and income of farmers with the achievement percentage of $89.6 \%$ and $89 \%$ respectively. With the existence of RAED grant, it was considered that it had helped many farmers, especially farmers who had micro-scale businesses. Loan funds intended for Farmer group and those managed by MFIA had been distributed to all Farmer group members in fulfilling their needs in the agricultural sector. Small farmers did not feel the lack of capital in the procurement of fertilizers or seeds because with the existence of RAED loan funds, farmers' needs were fulfilled, so that the farms run by farmers were smooth and provided increased income for farmers.

The next supporting factor on product indicators in CIPP model was the distribution of funds distributed. $87 \%$ of RAED funds had been distributed into agricultural sector and the rest was in the livestock sector and processing agricultural products. It was known that in District of Gunungkidul, in addition to cultivating agricultural crops, farmers also raised livestock as an income to increase farmers' income. Then $80.3 \%$ of DAP-RAED funds had been distributed to poor farmers. It was known that District of Gunungkidul had the highest poverty rate compared to other districts in Special Region of Yogyakarta. Therefore, with the existence of this DAP-RAED fund, the distribution of funds had been right on target, belonging to the criteria of poor farmers because they had micro-scale businesses. According to the explanation of each indicator in the CIPP model above, it could be concluded that total performance assessment of MFIA using the CIPP method (Context, Input, Process, Product) was presented in the Table 7.

According to Table 7 above, the total performance measurement of MFIA in District of Gunungkidul obtained score of 59.07 which was included in criteria of good. According to total obtained score using CIPP model, the MFIA included in good criteria. Only indicators product in CIPP model that classified as very good criteria. This meant that quantity and quality of RAED program implementation had been assessed to be maximal, in line with expectations and on target in accordance with the objectives of the RAED program, that was to help capital for micro-scale farmers.

\section{Conclusion}

The performance of MFIA in District of Gunungkidul included in the criteria of good performance. Performance measurement used evaluation method program with CIPP model (Context,
Input, Process, Product). In terms of improving the performance of MFIA in District of Gunungkidul, it is expected that there would be routine assistance from the companion, that was PMT in managing financial reporting in accordance with the standard provisions. Then assistance and support to MFIA on the importance of legal entities, thus, MFIA had a relationship in terms of increasing capital so that the number of borrowers was expected to increase.

\section{ACKNOWLEDGMENT}

The author want to acknowledge the Agribusiness Microfinance Institutions (MFIA) that have given space to the author in examining the performance in Gunungkidul Regency

\section{Conflict of interest}

The authors declare there are no conflicts of interest.

Open Access: This is an open access article distributed under the terms of the Creative Commons Attribution 4.0 License, which permits unrestricted use, distribution, and reproduction in any medium, provided the original author(s) if the sources are credited.

\section{REFERENCES}

Hakan, K. and Seval, F. (2011). CIPP evaluation model scale : development, reliability and validity. Procedia - Social and Behavioral Sciences, 15: 592-599, https://doi.org/10.1016/j.sbspro.2011.03.146

Kurniati, S.A. (2016). Impact of Implementation of Rural Agribusiness Business Development Program (PUAP) in Indragiri Hulu Regency. Jurnal Agribisnis, 18.

Ministry of Agriculture. (2014). Guidelines for Development of MFIA in Gapoktan RAD. Directorate of Agricultural Financing.

Ministry of Agriculture. (2010). General Guidelines for Agribusiness Business Development Rural (PUAP). Ministry of Agriculture. Jakarta.

Nawawi, H. (2017). Performance Evaluation and Management in Corporate and Industrial Environments. Yogyakarta: Gadjah Mada University Press.

Nugroho, A.D., Waluyati, L.R. and Jamhari. (2018). Evaluation of Rural Agribusiness Business Empowerment Program (PUAP) of the Special Region of Yogyakarta, 8: 111-212, https://doi.org/10.22146/kawistara.32086

Saleh, Yopi, Sugihono, Chris and Hanifah, V.W. (2013). Performance of Agribusiness Microfinance Institutions in Bantul Regency, Yogyakarta Province, 16(3): 212-222.

Saragih, B. (2015). Voice of Agribusiness 2: Collection of Thinking Bungaran Saragih. Jakarta: PT. Sustainable Discourse Jewels and Gaung Persada Press.

Setijowati, R. (2012). The Effectiveness, Efficiency, and Sustainability of Agribusiness Microfinance Institutions (MFIA) in the Special Region of Yogyakarta. 2012. Gadjah Mada University.

Statistics, C.B. of. (2017). Poverty Data of Gunungkidul District, Special Region of Yogyakarta. Retrieved from http://yogyakarta.bps.go.id/ 
Stufflebeam, D.L. (2003). The CIPP Model for Evaluation. International Handbook of Educational Evaluation. USA: Kluwer Academic Publisher.

Stufflebeam, D.L. (1971). The use of experimental design in educational evaluation. Journal of Educational Measurement, 8(4), 267-274.
Suryahadi, A. (2017). Good Evaluation Requirements and Elements in the Collection of Monitoring and Evaluation of Poverty Alleviation Programs.

Utami, R.A. (2015). Sustainability Analysis and Development Pattern of CoOperative Entrepreneurship Agribusiness Microfinance Institutions, 65-77. 